\title{
PENERAPAN TEKNOLOGI ALAT PENANAM BENIH JAGUNG TIPE ROW SEEDER DI KELOMPOK TANI SUKA MAJU UNTUK MENDUKUNG KETAHANAN PANGAN WILAYAH PERBATASAN KALIMANTAN UTARA
}

\author{
Dwi Santoso1), Galih Yogi Rahajeng"), Saat Egra1) \\ 1)Program Studi Agroteknologi, Fakultas Pertanian, Universitas Borneo Tarakan, Tarakan, \\ Kalimantan Utara, Indonesia \\ 2)Program Studi Agribisnis, Fakultas Pertanian, Universitas Borneo Tarakan, Tarakan, \\ Kalimantan Utara, Indonesia \\ Corresponding author : Dwi santoso \\ E-mail : dwiborneo11@gmail.com
}

Diterima 07 September 2021, Direvisi 22 September 2021, Disetujui 22 September 2021

\begin{abstract}
ABSTRAK
Permasalahan yang dihadapi oleh Kelompok tani Suka Maju hingga saat ini yaitu masih menggunakan metode manual dalam proses penanaman benih jagung, hal ini membuat waktu pengerjaan lebih lama dan posisi lubang tidak sejajar dan presisi. Dampak dari dua hal tersebut yaitu akan menambah biaya tenaga kerja dan posisi jagung yang tidak sejajar ataupun berhimpitan akan membuat petumbuhan tanaman jagung tidak optimal. Pengabdian ini bertujuan untuk menerapkan teknologi alat penanam benih tipe row seeder untuk mengurangi jerih kerja petani pada saat proses penanaman benih khususnya tanaman jagung. Kegiatan PKM ini dilakukan di lahan Kelompok tani Suka Maju Kelurahan Juata Laut Kecamatan Tarakan Utara, Kota Tarakan. Kegiatan ini dibagi dalam beberapa tahapan yaitu survey, sosialisasi, pembuatan alat, bimbingan teknis serta evaluasi pelaksanaan dan keberlanjutan program oleh Kelompok Tani. Kegiatan PKM penerapan teknologi alat penanam tipe row seeder di kelompok tani Suka Maju berjalan dengan baik serta para petani bersemangat untuk mengaplikasikan alat penanam di setiap lahan mereka. Selain itu terjadi peningkatan efisiensi dalam proses budidaya tanaman jagung dikelompok tani suka maju yaitu proses penananam jagung bisa lebih cepat $45 \%$ dibandingkan pada saat penanaman benih jagung secara manual
\end{abstract}

Kata kunci: penerapan; alat penanam benih jagung; tipe row seeder,

\begin{abstract}
The problem faced by the Suka Maju farmer group until now is that they still use manual methods in the process of planting corn seeds, this makes the processing time longer and the position of the planting holes is not parallel and precise. The impact of these two things is that it will increase labor costs and the position of corn that is not parallel or coincides will make corn plant growth not optimal. This service aims to apply row seeder type seed planter technology to reduce the labor of farmers during the seed planting process, especially for corn plants. This PKM activity was carried out on agricultural land belonging to the Suka Maju farmer group, Juata Laut Village, North Tarakan District, Tarakan City. This activity is divided into several stages, namely survey, socialization, tool making, technical guidance and evaluation of the implementation and sustainability of the program by the Farmer Group. The PKM activity for the application of row seeder type planter technology in the Suka Maju farmer group is going well and the farmers are excited to apply the planter in each of their lands. In addition, there is an increase in efficiency in the corn cultivation process in the advanced farmer group, namely the corn planting process can be $45 \%$ faster than when planting corn seeds manually.
\end{abstract}

Keywords: application; corn seed planter; row seeder type,

\section{PENDAHULUAN}

Kondisi dan potensi yang ada di Kecamatan Tarakan Utara, Kota Tarakan memungkinkan hampir semua komoditi dari usaha tani dapat dibudidayakan dan dikembangkan. Namun kegiatan usahatani di wilayah Kecamatan Tarakan Utara masih menerapkan metode tradisional dalam proses budidayanya, kurangnya penggunaan alsintan pada setiap tahapan budidaya mulai dari pengolahan tanah hingga pemanenan berdampak pada waktu, biaya dan tenaga yang tidak efisien. Kurangnya petani yang menggunakan alsintan di kota Tarakan juga menyebabkan masih rendahnya produktifitas tanaman. Penggunaan alat dan mesin pertanian (alsintan) di era pertanian modern telah menjadi kebutuhan utama para petani 
dalam proses pengelolaan aktivitas budidaya tanaman seperti mengolah tanah, menanam, pemanenan hingga pengolahan menjadi suatu produk, mengingat tenaga kerja/buruh tani yang semakin sulit diperoleh dan mahal. Penggunaan alat dan mesin pertanian bertujuan untuk meningkatkan luas tanah yang diolah dan intensitas penanaman (Santoso \& Waris, 2020). Penerapan alat dan mesin pertanian juga berperan untuk meningkatkan produktivitas dan efisiensi usahatani, menekan kehilangan hasil, meningkatkan mutu dan nilai tambah produk (Amrullah ${ }^{1} \&$ Hadi, 2016). Disisi lain terjadi peningkatan peluang kerja melalui terciptanya sistem agribisnis terpadu yang pada akhirnya akan semakin memacu pertumbuhan ekonomi masyarakat kota Tarakan melalui sektor pertanian. Hasil penelitian (Hermawan, 2011) menjelaskan bahwa terjadi peningkatan efisiensi pada penggunaan traktor tangan di lahan pasang surut yaitu sekitar $80 \%$. Alat penanam benih jagung juga mampu meningkatkan efisiensi waktu penanaman hingga $85 \%$ (Santoso et al., 2020).

Proses budidaya tanaman jagung dilahan yang luas akan merepotkan petani jika tidak diimbangi dengan pemakaian alat dan mesin pertanian yang mampu memudahkan pekerjaan para petani. Oleh karena itu pada setiap tahapan kegiatan budidaya mulai dari pengolahan tanah, penyemaian, penanaman, pemeliharaan hingga pemanenan harus menggunakan peralatan pertanian yang bisa membantu memudahkan dan memercepat pekerjaan petani. (Sitorus et al., 2015) menjelaskan bahwa peningkatan efisiensi waktu, tenaga dan biaya pada setiap tahapan budidaya dapat diimplementasikan melalui penggunaan alat dan mesin pertanian yang tepat guna dan sesuai dengan kondisi sosial dan wilayah petani setempat.

Kelompok tani Suka Maju hingga saat ini masih menggunakan metode manual dalam proses penanaman benih jagung, hal ini membuat waktu pengerjaan lebih lama dan posisi lubang tidak sejajar dan presisi. Dampak dari dua hal tersebut yaitu akan menambah biaya tenaga kerja dan posisi jagung yang tidak sejajar ataupun berhimpitan akan membuat petumbuhan tanaman jagung tidak optimal. (Santoso et al., 2021) menjelaskan bahwa proses penanaman tanaman jagung menggunakan tangan (manual) tanpa bantuan peralatan pertanian akan mengurangi efisiensi lapang sebesar $35 \%$ sedangkan yang menggunakan peralatan pertanian (alsintan) memiliki efisiensi lapang sebesar $85 \%$. Di sisi lain faktor biaya yang membuat petani tidak banyak menggunakan alat dan mesin pertanian. kondisi kota Tarakan yang berbentuk pulau kecil dan hanya bisa dilalui oleh akses laut dan udara membuat harga jual peralatan pertanian juga tinggi. oleh karena itu diperlukan suatu alat penanam benih jagung yang tepat guna untuk membantu meningkatkan produktifitas tanaman jagung.

Berdasarkan hasil analisis situasi wilayah Kecamatan Tarakan Utara, Kota Tarakan maka diperlukan kegiatan PKM bidang mekanisasi pertanian di lahan usahatani berbasis teknologi tepat guna. Penerapan teknologi yang tepat guna, murah dan aplicable sangat diperlukan untuk mengatasi masalah penanaman yang masih menggunakan cara manual sehingga mampu meningkatkan efisiensi waktu, tenaga dan biaya. Penerapan teknologi tepat guna alat penanam benih jagung tipe row seeder merupakan salah satu pilihan untuk meningkatkan produktivitas tanaman dan mendukung peningkatan pangan wilayah perbatasan khususnya wilayah Kota Tarakan

\section{METODE}

Kegiatan PKM ini dilakukan di lahan usahatani Kelompok tani Suka Maju Kelurahan Juata Laut Kecamatan Tarakan Utara, Kota Tarakan, Kalimantan Utara. Kegiatan ini dibagi dalam beberapa tahapan yaitu survey, sosialisasi, bimbingan teknis serta evaluasi pelaksanaan dan keberlanjutan program oleh Kelompok Tani. Program PKM ini rencananya dilaksanakan selama 8 bulan.

\section{Survei}

Survei potensi dan kelayakan wilayah dilakukan di objek pelaksanaan kegiatan PKM dengan melakukan pendataan hasil usahatani dan komoditi unggulan Kelompok Tani (Santoso et al., 2018). Tahapan ini juga dilakukan analisis permasalahan yang dihadapi oleh kelompok tani dan sistem budidaya tanaman pada lahan usahatani.

\section{Sosialisasi}

Kegiatan ini akan dilakukan dalam bentuk diskusi interaktif langsung dan pelatihan lapang kepada anggota di Kelompok tani Suka Maju sebagai mitra dengan tujuan membuka wawasan dan peningkatan soft skill mengenai pengoperasian dan perawatan alat penanam benih jagung tipe row seeder lahan usahatani. Pada tahapan ini juga akan dilakukan penyuluhan dan bimbingan teknis tentang penerapan teknologi tepat guna yang murah dan aplikatif dilahan usahatani. Kegiatan ini dilakukan kerjasama dengan Dinas Pertanian dan Kelurahan Juata Laut sebagai sasaran kegiatan PKM.

3. Bimbingan Teknis
Pada kegiatan ini dilakukan
pemberdayaan Kelompok tani Suka Maju ,


seluruh kegiatan PKM alat penanam benih jagung tipe row seeder akan melibatkan langsung anggota Kelompok Tani. Anggota Kelompok tani Suka Maju dilibatkan dalam pelaksanaan program seperti penyiapan alat dan bahan yang akan digunakan, perancangan dan perakitan alat, pengujian dan penerapan lapang. Analisis kelayakan dilakukan dengan pedampingan yang berkala dan berkesinambungan serta dampak pelaksanaan program PKM. Partisipasi masyarakat dalam pelaksanaan program PKM dilakukan melalui keikutsertaan masyarakat dalam memberikan kontribusi guna menunjang pelaksanaan program yang berbentuk tenaga, barang ataupun informasi. Partisipasi masyarakat diharapkan mulai dari tahap perencanaan, pelaksanaan, pemanfaatan hasil hingga pada tahap evaluasi pelaksanaan program PKM. Masyarakat memberikan tenaga dalam pelaksanaan program PKM khususnya perancangan, penerapan, menjaga dan merawat fasilitas yang diimplementasikan. Partisipasi berbentuk informasi dapat diberikan melalui data komoditi unggulan dan deskripsi lahan usahatani, sedangkan partisipasi dalam bentuk barang dapat meminjamkan barangbarang yang dimiliki oleh warga dalam rangka pelaksanaan program PKM dan penyediaan tempat rapat/workshop (Sirait et al., 2019).

\section{Evaluasi pelaksanaan dan keberlanjutan program}

Evaluasi merupakan suatu proses pengungkapan masalah kinerja dari suatu kegiatan untuk memberikan umpan balik bagi peningkatan kualitas kinerja kegiatan tersebut. Adapun tujuan evaluasi adalah untuk mendapatkan informasi dan menarik pelajaran dari pengalaman mengenai pengelolaan suatu program (keluaran, manfaat, dan dampak) baik dari program yang baru selesai maupun yang sudah berfungsi, sebagai umpan balik bagi pengambilan keputusan untuk perencanaan program selanjutnya. Fokus utama evaluasi dari program PKM di Kelompok tani Suka Maju Kecamatan Tarakan Utara, Kota Tarakan diilustrasikan oleh hubungan antara variabel inti evaluasi, yaitu evaluasi dampak, efisiensi, efektivitas, relevansi, dan keberlanjutan. Berikut penjelasan mengenai variabel-variabel inti evaluasi tersebut.

1) Efisiensi, didefinisikan sebagai hubungan jumlah dan kualitas output yang dihasilkan dengan sumberdaya yang dikeluarkan. Total biaya output sama dengan jumlah biaya berbagai input kegiatan yang digunakan untuk menghasilkan output berupa hasil panen Kelompok Tani (Fithri \& Sari, 2016).
2) Efektivitas, menunjukkan sejauh mana output yang direncanakan, efek yang diharapkan, dan dampak yang dimaksudkan dapat tercapai terutama peningkatan peningkatan efisiensi lapang dan produktivitas tanaman yang dibudidayakan oleh Kelompok tani Suka Maju .

3) Relevansi, menilai sejauh mana program menempatkan masalah pada prioritas utama, terutama dilihat dari sudut pandang stakeholder, khususnya oleh penerima manfaat program (Murdianto \& Santoso, 2021). Pada tahap ini dilakukan penilaian terhadap kesesuaian kegiatan PKM menjadi solusi untuk menyelesaikan permasalahan yang dihadapi oleh Kelompok tani Suka Maju yaitu belum adanya penerapan teknologi tepat guna pada proses penanaman.

4) Dampak, lazimnya bersifat jangka panjang, berupa konsekuensi tidak langsung yang luas dari kegiatan PKM yang dimaksudkan oleh penerima manfaat. Dampak dapat dibedakan menurut dampak positif maupun dampak negatif sesuai dengan sudut pandang penilaianya. Tahap ini dilakukan penilaian terhadap hasil panen dan peningkatan produktivitas sumberdaya lahan Kelompok tani Suka Maju sebelum dan sesudah kegiatan PKM

5) Keberlanjutan, merupakan pemeliharaan atau pengaruh tambahan perubahan positif yang dihasilkan oleh program sesudah program PKM selesai dilaksanakan (Pramono \& Nainggolan, 2015). Melalui tindakan keberlanjutan diharapkan program dapat dilanjutkan baik oleh Kelompok Tani ataupun oleh kelompok tani yang lain. Tahap ini juga dilakukan monitoring dengan melakukan kunjungan ke lahan Kelompok Tani setiap bulan dan dilakukan kerjasama untuk kegiatan praktikum mahasiswa.

\section{HASIL DAN PEMBAHASAN}

\section{Survei Lanjutan}

Kelompok Tani Suka Maju merupakan salah satu wadah komunikasi antar petani wilayah Kecamatan Tarakan Utara dan terletak di Jalan P. Aji Iskandar, Kelurahan Juata Laut, Kecamatan Tarakan Utara, Kota Tarakan yang dipimpin oleh Bapak Mursito. Masing-masing anggota kelompok tani memiliki lahan seluas 12 ha sebagai lahan usaha taninya dengan komoditi unggulan yang menjadi bidang usahanya adalah tanaman jagung dan sayursayuran Survey lanjutan dilakukan untuk menggali informasi yang lebih dalam mengenai 
permasalahan yang dialami oleh para petani, Adapun beberapa permasalahan yang ditemui di kelompok tani Suka Maju diantaranya :

1. Petani dalam proses budidaya sebagian besar masih menggunakan metode manual

2. Pemakaian alat dan mesin pertanian belum digunakan pada setiap tahapan budidaya

3. Metode penananam benih jagung masih menggunakan cara manual sehingga membutuhkan waktu yang lama dan proses penanaman tidak presisi

4. Terjadi penurunan produksi dan produktifitas tanaman jagung

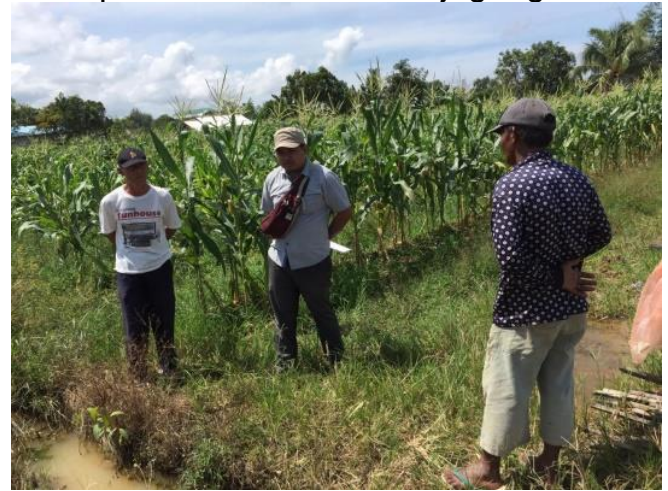

Gambar 1. Survei lanjutan

(Sumber: Dokumentasi pribadi)

\section{Sosialisasi}

Sosialisasi dilakukan di lahan terbuka milik salah satu petani di kelurahan juata laut dengan menerapkan protokol kesehatan yang ketat yaitu memakai masker dan menjaga jarak. Kegiatan secara tatap muka ini diikuti oleh sekitar 10 petani. metode sosialisasi dilakukan dengan diskusi terbuka dengan memaparkan tujuan kegiatan dan hasil survey yang telah dilakukan sebelumnya. Beberapa hal yang disepakati di dalam pelaksanaan sosialisasi tersebut diantaranya penentuan lokasi kegiatan, waktu pelaksanaan kegiatan dan metode pelaksanaan kegiatan PKM hingga selesai.

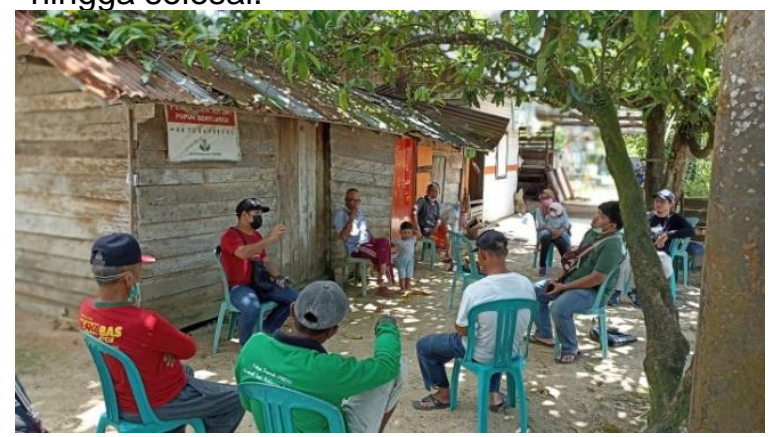

Gambar 2. Kegiatan sosialisasi kegiatan PKM

(Sumber: Dokumentasi pribadi)

\section{Pembuatan Alat}

Pembuatan alat dilakukan melalui beberapa tahapan yaitu, perancangan alat, pembelian bahan dan komponen penyusun serta perakitan. Salah satu kelebihan alat ini adalah tidak hanya bisa digunakan untuk penanaman jagung, tetapi bisa untuk penanaman palawija yang lain seperti kedelai, kacang hijau, dll. Hal ini dikarenakan bagian roller sudah didesain dengan berbagai macam ukuran diameter benih. Baik ukuran benih jagung, kedelai ataupun yang lainnya. Adapun spesifikasi ukuran roller adalah panjang $70 \mathrm{~mm}$ dan diameternya 45,8 mm. Sedangkan dimensi lubang benih untuk 1 lubang berukuran diameter $10.5 \mathrm{~mm}$ kedalaman $7 \mathrm{~mm}$. Alat tanam benih jagung ini pengoperasiannya sangat mudah. Tempat benih yang berkapasitas $3 \mathrm{~kg}$ diisi benih terlebih dahulu. Selanjutnya alat digerakkan maju dan secara otomatis benih jagung akan langsung tertanam dengan kedalaman tanah yang seragam. Keluaran benih ini dapat dikotrol dengan lubang roller yang disesuaikan dengan diameter jagung. Alat ini dapat mengeluarkan 1 atau 2 butir benih jagung sesuai pengaturan. Alat ini juga dapat dipakai untuk menanam tanaman yang lain, seperti kedelai atau kacang hijau. Dengan penyetelan lubang yang sudah ada dalam roller katu benih yang disesuaikan dengan diameter benih kedelai atau kacang hijau, alat dapat digunakan dengan baik.

Spesifikasi teknis alat penanam benih tipe row seeder adalah sebagai berikut:

1. Bodi terbuat dari alumunium dan stainless steel sehingga kuat

2. Volume lubang tanam 1-2 biji benih

3. Kedalaman tanah : $6-8 \mathrm{~cm}$

4. Jarak penanaman benih : $20-25 \mathrm{~cm}$

5. Jumlah mulut tanam : 8

6. Efisiensi : 2 hektar/jam

7. Berat : $9 \mathrm{~kg}$

8. Kapasitas tabung benih : $3 \mathrm{~kg}$

9. Desain ergonomis

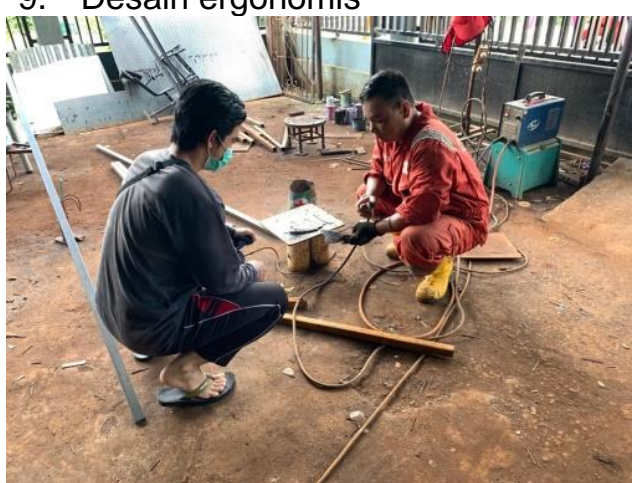

Gambar 3. Pembuatan alat penanam tipe row seeder

(Sumber: Dokumentasi pribadi) 


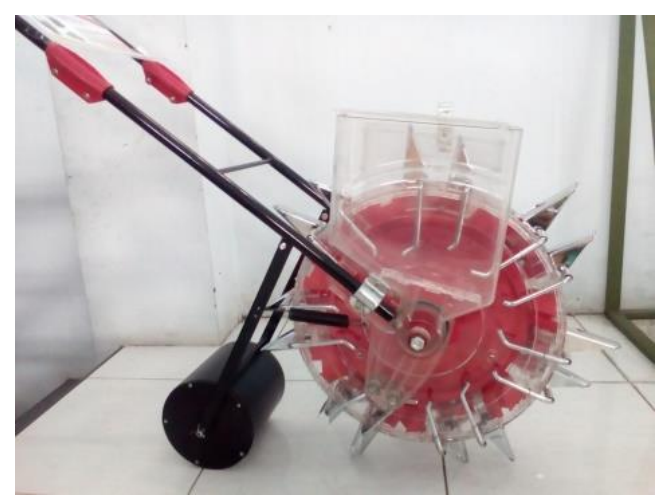

Gambar 4. Hasil akhir pembuatan alat penanam tipe row seeder (Sumber: Dokumentasi pribadi)

\section{Bimbingan Teknis}

Bimbingan teknis dilakukan di lahan budidaya tanaman jagung dan bengkel pertanian milik salah satu petani, kegiatan ini terdiri dari dua kegiatan yaitu (1) pelatihan perakitan dan perbaikan alat penanam, (2) pelatihan pengoperasian alat di lapangan. Pelatihan perakitan dan perbaikan alat penanam tipe row seeder dilakukan di bengkel pertanian milih salah satu petani, pelatihan berjalan dengan baik dan petani antusias mengikuti kegiatan. Materi yang diajarkan ke petani yaitu bagaimana proses perakitan box dan mulut tanam, serta bagaimana menyesuaikan jarak tanam dan jumlah benih yang keluar dengan cara mengganti plant rotary sesuai kebutuhan. Kemudian kegiatan selanjutnya dilanjutkan di lahan jagung seluas $5000 \mathrm{~m}^{2}$ milik salah satu anggota kelompok tani Suka Maju yaitu pengoperasian alat secara langsung di lapangan. Lahan yang dipilih berdasarkan target pengoperasian yaitu pada lahan yang siap ditanami benih jagung. Pengoperasian dilakukan langsung oleh petani dengan mempraktekan proses penanaman benih jagung sekaligus pemupukan menggunakan alat penanam tipe row seeder, proses penanaman dilakukan pada bedengan yang belum dilakukan proses penanaman.

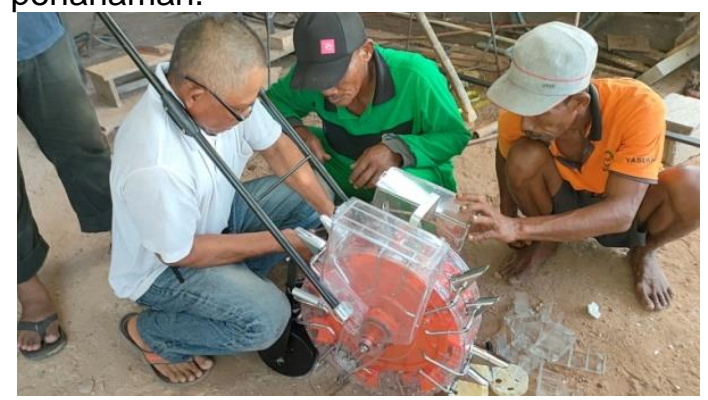

Gambar 5. Bimbingan teknis perakitan alat (Sumber: Dokumentasi pribadi)

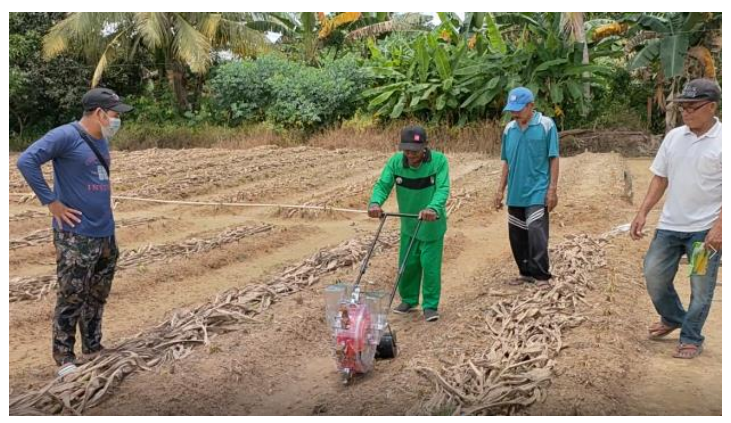

Gambar 6. Bimbingan teknis penerapan alat penanam

(Sumber: Dokumentasi pribadi)

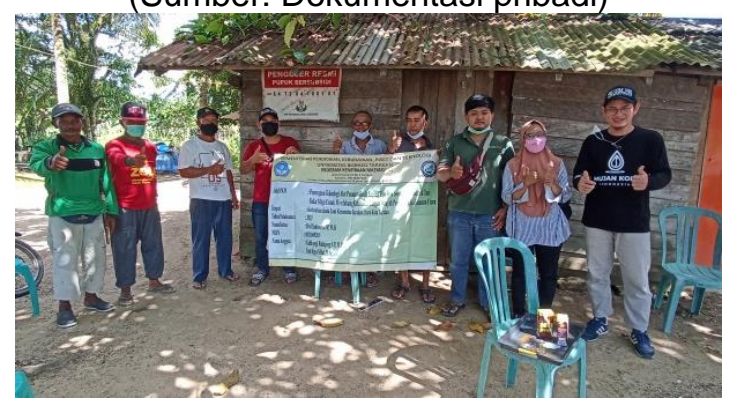

Gambar 7. Foto bersama dengan petani (Sumber: Dokumentasi pribadi)

\section{Evaluasi}

Pada tahap terakhir dari kegiatan pelatihan ini adalah evaluasi kegiatan dan rencana tindak lanjut. Respon positif dan antusias para petani cukup baik, pelaksanaan pelatihan dan transformasi ilmu pengetahuan dan teknologi alat penanam tipe row seeder dari tim PKM berjalan dengan lancar. Langkah selanjutnya yaitu yang dilakukan tim PKM adalah diskusi atau wawancara non formil untuk mendapatkan informasi dari mitra pengabdian dalam hal ini kelompok tani Suka Maju tentang peningkatan pengetahuan dan manfaat yang telah didapatkan dari kegiatan PKM ini.

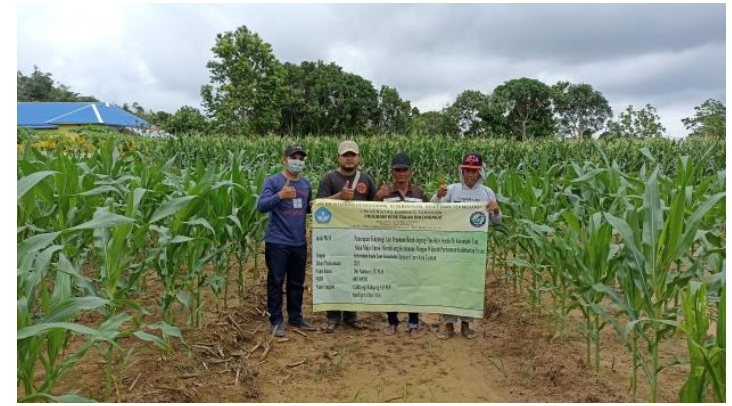

Gambar 8. Foto bersama dengan petani di lahan tanaman jagung

(Sumber: Dokumentasi pribadi)

\section{SIMPULAN DAN SARAN Simpulan}

Kegiatan PKM penerapan teknologi alat penanam tipe row seeder di kelompok tani Suka Maju berjalan dengan baik serta para petani bersemangat untuk mengaplikasikan alat 
penanam di setiap lahan mereka. Selain itu terjadi peningkatan efisiensi dalam proses budidaya tanaman jagung dikelompok tani suka maju yaitu proses penananam jagung bisa lebih cepat $45 \%$ dibandingkan pada saat penanaman benih jagung secara manual.

\section{Saran}

Perlu dilakukannya proses transfer teknologi yang lebih modern dengan menerapkan mesin penanam dan pemanen jagung sehingga kegiatan budidaya tanaman jagung akan semakin lebih efisien sehingga mampu meningkatkan produksi dan pendapatan petani.

\section{UCAPAN TERIMAKASIH}

Terima kasih kami haturkan kepada kelompok tani Suka Maju serta ketua RT bapak Pujiono atas bantuannya sehingga kegiatan PKM ini dapat berjalan dengan baik dan lancar, tidak lupa pula kami sampaikan ucapan terima kasih kepada Kementerian pendidikan, kebudayaan, riset dan teknologi yang telah mensupport dalam pendanaan PKM ini.

\section{DAFTAR RUJUKAN}

Amrullah1, E. R., \& Hadi, S. N. (2016). Peran Dan Kontribusi Hand Tractor Terhadap Efisiensi Usahatani Di Banten.

Fithri, P., \& Sari, R. Y. (2016). Analisis Pengukuran Produktivitas Perusahaan Alsintan CV. Cherry Sarana Agro. Jurnal Optimasi Sistem Industri, 14(1), 138-155.

Hermawan, W. (2011). Perbaikan Desain Mesin Penanam Dan Pemupuk Jagung Bertenega Traktor Tangan. Jurnal Keteknikan Pertanian, 25(1).

Murdianto, D., \& Santoso, D. (2021). Sosialisasi Persiapan Pembelajaran Di Masa New Normal Bagi Guru SMK Di Kota Tarakan. Amalee: Indonesian Journal Of Community Research And Engagement, 2(1), 53-62.

Pramono, R., \& Nainggolan, R. (2015). Model Sinergi Perguruan Tinggi Dan Perusahaan Dalam Kegiatan Pengabdian Kepada Masyarakat Di Kec. Mauk Tangerang. Ekonomi, Sosial Dan Budaya, 212.

Santoso, D., Muhidong, D., \& Mursalim, M. (2018). Model Matematis Pengeringan Lapisan Tipis Biji Kopi Arabika (Coffeae Arabica) Dan Biji Kopi Robusta (Coffeae Cannephora). Jurnal Teknologi Pertanian Andalas, 22(1), 86-95.

Santoso, D., Rahajeng, G. Y., \& Wijaya, R. (2020). Identifikasi Kebutuhan Alsintan Tanaman Pangan (Padi Dan Jagung) Di Kota Tarakan. Jurnal IImiah Inovasi, 20(3).
Santoso, D., \& Waris, A. (2020). Uji Kinerja Sistem Kontrol Untuk Pengendalian Suhu Pada Alat Pengering Biji-Bijian Berbasis Fuzzy Logic. Jurnal Ilmiah Rekayasa Pertanian Dan Biosistem, 8(1), 33-39.

Santoso, D., Waris, A., Apriliansyah, A., Sirait, S., \& Murtilaksono, A. (2021). Desain Dan Uji Kinerja Mata Pisau Modifikasi Pada Mesin Pencacah Limbah Pertanian. Jurnal Teknologi Pertanian Andalas, 25(2), 205-214.

Sirait, S., Santoso, D., \& Egra, S. (2019). Teknologi Irigasi Otomatis Bertenaga Surya Di Kelompok Tani Cahaya Tani Kecamatan Tarakan Utara Kota Tarakan. J-PEN Borneo: Jurnal IImu Pertanian, 2(2).

Sitorus, A., Hermawan, W., \& Setiawan, R. P. A. (2015). Pengembangan Mesin Penanam Dan Pemupuk Jagung Terintegrasi Dengan Pengolahan Tanah Alur. Jurnal Keteknikan Pertanian, 3(2). 